\title{
Kingship and Love
}

In almost all narratives discussed until now the intrigue is at least partly built on issues of love, sexuality, eroticism, or adultery. It can be argued that there is hardly any fictional text that does not in some way or other refer to the relationship between men and women, and that the references in these texts therefore do not add significance to their potential meaning. In fact, as suggested in Chapter One, the love intrigues in the story may be no more than a device to insert a dramatic element into the narrative to turn it into a form of fiction. Still, from our discussion it is clear that the intervention of women, and concomitantly the intricacies of love and sexuality, play an important role in organizing and imaging concepts, arguments, and roles. It is perhaps justified to say that by often being the instigator of the dramatization of events, women represent an additional layer within the discursive representations of kingship. Here, again, it is clear in most cases that power and authority are not monolithic phenomena, concentrated in one person and one discourse, but are composed of different roles and various discursive elements.

It is remarkable that in spite of the omnipresence of women in our narratives, there is no woman presented as possessing absolute power or as a symbol of rulership. Women are often staged as destroyers of imperial harmony or dynastic stability, but they are not normally rulers themselves. Although they have a prominent role, they are still in many respects marginalized, relegated to a subordinate discourse rather than integrated into the main discourse of ideal kingship. In some cases they even represent a counter-discourse inserted to more forcefully construct the pretensions of male dominance. The omnipresence of women indicates, too, that they are in several ways endowed with power and authority, either because they share in the claims to legitimacy of the king, or because of their power to challenge constructions of male authority by their sexual powers and appeal to the emotions. In both cases, their freedom to act is restrained by traditions and conventions that impose obedience and prescribed forms of propriety.

It is the incongruence between the powers of women and their essentially subservient roles that brings forth their potential as a source of narrative intrigues. Their roles can roughly be summarized as twofold. First, in the cycles analysed in the first two chapters women are depicted as the embodiment of irrationality, perfidy, emotions, and unreliability. The imperial and royal spouses and concubines literally throw in their body to challenge the abstract 
principles of kingship, by manipulating princes, emperors, and kings, forcing them to reconsider their roles. As we have argued above, through this manipulation they introduce a situation of interruption and, more importantly, of dialogue, a mechanism to revitalize and restore the foundations of authority. They are, so to speak, the ones who break the silence under which the principles of sound, rational rule lie hidden. In this clearly misogynous view, the basic rule is that the element represented by women should be controlled, disciplined, and encapsulated in a discourse of rationality.

The second set of roles, which is much more positive, is found in several of the chivalric romances discussed in Chapter Three. In some of the romances the role of women is completely marginal. In Yue Fei, for instance, the main female characters are Yue Fei's mother, who secures his survival after the flood, the gallant wife of a provincial governor who leads the defence of the city, and the wife of Prime Minister Zhang, who prevents 'human relationships' from falling apart by letting the emperor escape. There is, of course, also a perfidious concubine. In Sayyid Battal the role of women is even more marginal since it is virtually reduced to either victims of male aggression or objects of the lust of the hero. Similarly, in Hang Tuah women are seductive but completely subjected to men, although in one episode the hero is rather permissively entertained by a queen. In Baybars, finally, women are more prominent. In Damascus the young Baybars is 'adopted' by a notable lady; in Cairo Baybars defends young women lusted after by wicked old men; and Shajarat al-Durr, the wife of al-Salih Ayyub, plays a prominent role in the struggle for the succession of the king. Moreover, Baybars marries a Mongolian girl and promises her to remain monogamous. In these stories women are not part of the structure of power, but rather 'objects', which are instrumental, rather than essential, in preserving the structure of male power, both morally and practically.

The cases of Tirant and Hamza are more complex. Here, women are involved in the structures of power and authority, and there is some attention to the various aspects of the phenomenon of love. In Tirant love is present from the very beginning, when William of Warwick, intending to retreat from public life after his pilgrimage, says farewell to his wife. In the tournament in which Tirant participates women have their familiar courtly role. They are the symbolic beloveds of the knights who pledge to fight and strive in their honour, and they are even included in the membership of the new order founded by the English king. Women clearly represent the complementary component within the concept of knighthood: They are the standard of virtue and loyalty, and therefore add a symbolic, cultural element into a system which is based on formal acknowledgement and hierarchy, and, of course, power and fighting. Later Tirant arranges the marriage between one of the princes of France and 
the princess of Sicily, an episode that exploits the playfulness of erotic advances and combines it with the exigencies of dynastic procreation: marriage is meant not only to perpetuate the dynasty, but also to link the main royal families of Christianity.

Tirant is thus not adverse to eroticism and love, and the two elements converge in his protracted courting of the Byzantine Princess Carmesina. This courtship not only gives occasion for several farcical scenes-Tirant breaking a leg while climbing out of Carmesina's bedroom-and for quite explicit descriptions of their erotic encounters; it also results in somewhat elaborate contemplations and exchanges about the nature of love, the nature of women, and the rules of propriety. Tirant is perplexed by his new and overwhelming sensations of love, disturbing his usual boldness, and the actual story is interrupted several times for polemic debates about love and the ways it should be effectuated into sexual union. These debates involve not only Tirant and the princess but also several ladies of the court and friends of the hero, who either encourage or rebuke the two lovers. In the arguments many references are made to Classical history, literature, and mythology, thereby incorporating the experience of the lovers in a cultural, moral, and aesthetic framework. In a narrative sense, the love component is an instrument for deferral: as long as the courtship of the hero continues, the story can unfold without suspense slackening, until in the end legal marriage and the defeat of the Turks conclude the narrative dynamics.

In a similar vein, in Hamzanama Princess Mehr-Nigar is the object of the hero's love. She is the precious jewel to whom all his endeavours are dedicated and who symbolizes his being accepted and acknowledged within the royal hierarchy, and the preservation of traditional legitimacy, which is in need of revitalization. The princess is actually the link between the two eras evoked in the narrative, the old Persian kingship of the Sassanids and the new moral and religious order of Islam. The continuity between the two is secured as soon as the son of Hamza and Mehr-Nigar ascends the throne. Apart from this key position in the imperial structure, Mehr-Nigar is also the distinguished recipient of Hamza's love. Like Tirant, Hamza is dumbfounded by his passion, and, like his French counterpart, he also breaks a leg while secretly visiting her bedroom. In Tirant with the setbacks in his courtship, due to vicious intrigues, considerations of decency, or narrative turns, the love element serves as a mechanism of postponement to preserve suspense while the story unfolds. Here, however, the beloved more and more transforms into a precious object, carried from one castle to another, without any real importance. The marriage is consummated at a certain point, but Hamza's love becomes diluted, and he has sexual relations with several other women and jinniyya's. 
As in Tirant, in Hamzanama, too, the force of the experience of love leads to contemplation, but in the latter work it is limited to the lament of the princess's female attendants:

Go take these tidings to your mother the nanny, [...] so that she may busy herself in effecting a remedy, and the violence of the princess' passion might subside in some way. Or else love- that destroyer of house and home-will spread roots, and its victim loses all sense of shame and decorum, and soils all name and honor. It disrupts the sane functioning of the mind, blanches the bright-red rose to a saffron-yellow hue, brings on raving madness, exposes one of the urchin's stone pelting; blights the one exposed to its breath, inverts the reason, makes one suffer cold sighs and hot lamentations with every breath, bids one to impetuously shatter the fragile glass of his name and honour, leaves one in complete stupefaction, causes one's head to be broken by stones, plugs one's ears with the cotton of heedlessness, and commands one not to lend one's ear to any counsel. ${ }^{1}$

Clearly, love is feared primarily for its destructive influence, and the concept of love expressed here contains both the potential unreliability of women and the necessity of the female contribution to the preservation of the dynasty. As in many Arabic romances, young princesses of a marriageable age are a danger to social stability, because they threaten the very foundation of patriarchal authority by conceding to their sexual impulses. Since women are the containers of the moral integrity of the community, the transition of women from paternal to matrimonial authority should be carefully and smoothly, but if necessary also forcefully, arranged.

From this brief survey we can now see more clearly the essential paradox of the female role in narratives of kingship: on the one hand, they are marginal, especially where official power and authority are concerned, but, on the other hand, they are powerful in their symbolic status; on the one hand, they are a threat to the stability and continuity of the dynasty, but, on the other hand, they have an essential role in securing dynastic continuity; on the one hand, they disrupt monologic discourses of authority, but, on the other hand, they are needed to open up and interpret the discourses of authority by creating dialogic situations; on the one hand, they disturb abstract, rational, principles with their physicality, but, on the other hand, they necessitate the harmonization of

1 Lakhnavi and Bilgrami, The Adventures of Amir Hamza, 184. 
these principles to specific events. By acting out these sometimes paradoxical roles, women become a vital part of the constellation of authority.

In the following sections we will discuss two clusters of narratives that are especially relevant for examining the element of love in pre-modern narratives of kingship. The first cluster concerns a network of Arabic-Persian and Hindavi love romances, which not only throws light on the combination of love and kingship as narrative themes, but also on the ways in which narrative material was recycled within the Islamic cultural realm. For the second cluster we turn to Europe to see how the chivalric romance gradually transformed into romances of love and, ultimately, the love-novel. Here we can see how the idea of the Orient played a crucial role in the development of European literature, especially within the genre of the romance, while later, from the seventeenth century onwards, the combination of exoticism and literary experiment gave rise to a new textual complexity, which seems to differentiate the European tradition from its Asian counterparts. This development, which is reflected in forms of self-reflexivity, using mirror-images and textual layers, becomes more prominent in the eighteenth century. We have already noticed this development in our discussion of Potocki's Manuscrit trouvé à Saragosse, in Chapter Three, and will encounter more examples in the present chapter and Chapter Six.

\section{The Prince and the Mysteries of Love}

We have argued above that processes of literary influence and transmission are both fluid and, to a certain extent, structured within historical embeddings, as is exemplified by the textual history of the Thousand and one nights. It is obvious from the collection itself that it contains material from various cultural spheres, Arabic and non-Arabic, Islamic and non-Islamic. Because of this diversity we can speak of the Thousand and one nights as a coherent text only from a relatively late date, perhaps no sooner than the end of the eighteenth century. Thus, the history of the text must be detached from the history of the separate stories, most of which have become part of the collection at a late stage. The fact that a certain story at a certain point was incorporated into the collection is not without significance, of course, but it tells us nothing about the trajectory it followed to arrive there. Even worse, its being integrated into the larger framework of the Nights may lead to new textual/philological and interpretive difficulties, because it may have been adapted or put in a different context.

In this section we will discuss the possible connections between three stories from the Thousand and one nights and two Indian romances that are so similar 
that a relationship inescapably imposes itself. The three Arabic stories are those of 'Sayf al-Muluk and Princess Badi al-Jamal', 'Janshah', and 'Qamar al-Zaman and Budur', all remarkable love/adventure stories. The Indian romances are the love/Sufi romances 'Mirigavati', by the Hindavi poet Qutban Suhravardi, written in 1503, and 'Madhumalati' by Manjhan Rajgiri, who began its composition in 1545. The similarities between these stories are so striking, that the problem for the researcher is not so much to prove their relationship, but rather to explain the differences. For this reason, we will dedicate considerable attention to aspects of textual history and then concentrate on aspects of discourses of kingship.

Within the diverse generic spectrum of the Thousand and one nights the stories of 'Sayfal-Muluk' and 'Janshah' belong to a special kind of love/adventure story, which involves the love union between man and jinn. In both cases a prince falls in love with a jinniyya and has to struggle to conquer her and arrange a steady relationship. In both cases one of the structuring elements is Solomon, who governs the domain of the forces of nature, the animals, and the jinn. The romance of 'Mirigavati' belongs to a particular group of poetic narratives that emerged in Delhi and the Eastern provinces of the Mughal Empire between the fourteenth and sixteenth centuries and that were connected with the religious upsurge and the rise of Sufi movements, especially the Chishti order, in this period. They were written in Hindavi and can be characterized as an amalgamation of love stories and Sufi allegories. They are remarkable most of all because of their syncretism, since they contain a curious mix of Hindi and Muslim elements and show traces of Persian, Arabic, Sanskrit, and popular literary influences. It is this internal compositeness combined with its layered meanings which makes it difficult to situate these stories in generic and cultural frameworks. Adding to the complexity, the unicity of these narratives seems to reveal that the contexts in which they should be fitted are far from clear and perhaps even more confusing than clarifying.

\section{The Story of 'Mirigavati'}

When the protagonist of the story of 'Mirigavati', Prince Raj Kunvar of Candragiri, is born, it is prophesied that he will suffer much grief because of a woman. ${ }^{2}$ As an adolescent, one day he sees a seven-coloured doe. He follows her, but she disappears into a lake, whereupon the prince builds a sumptu-

2 Qutban Suhravardi, The Magic Doe. Qutban Suhravardi's Mirigavati, trans. Aitya Behl (Oxford, 2012). 
ous palace on the bank. After some time he sees seven nymphs playing in the lake, and he captures one of them by stealing her sari. He declares his love for her, but Mirigavati-as she is called-is reluctant and wants to be his slave-girl only. Not long afterwards she flies away, summoning him, if he really covets her, to follow her to Kancanpur, the City of Gold. Raj Kunvar then dresses himself as a yogi and departs on his journey, asking travellers and hermits which way to go. He crosses a tumultuous ocean and escapes from man-eating serpents before arriving at a palace. Here a gorgeous princess is held prisoner by a demon who has captured her. The prince kills the demon and marries the princess, who is called Rupmini, but the union is not consummated.

Not long afterwards, the prince pretends to go hunting, but instead he takes a ship to continue the search for his beloved. On the way he is caught by a cannibal herdsman, with fearsome eyes, from whom he escapes by hiding in a goatskin. Then he reaches the Palace of the Doves, filled with magical birds, who show him the way to the City of Gold. After his arrival there Raj Kunvar is united with Mirigavati, and they indulge their passion. Later, Mirigavati forbids him to open one of the rooms of the palace, but the prince cannot contain his curiosity and is kidnapped by a demon, who throws him into the ocean. He survives, however, and finds his way back to the City of Gold. After their second reunion, Raj Kunvar returns to his hometown, picking up his other wife on the way, but the two wives are jealous and quarrel with each other. Finally, Raj Kunvar goes out to hunt and is killed by a tiger. His two spouses are burned and follow their husband in death.

Before discussing the themes and potential meanings of the story of 'Mirigavati', we will first summarize the stories of 'Janshah' and 'Sayf al-Muluk', to show the many similar motifs. The story of 'Janshah' begins in a typical fashion with an old king who has no heir. Astrologers advise him to marry a certain princess, and when a son is born, they predict that he will be exposed to great danger, but, if he survives, he will become powerful and happy. As a young man, Janshah goes out hunting with his friends and follows a beautifully coloured gazelle, who, however, escapes by jumping into the sea. Still, the company succeeds in catching the gazelle, but they decide to have a look at an island. On the way back they are blown out into to the open sea and lose their way. From here Janshah embarks on a journey over the seas, going from one marvellous island to another, meeting all kinds of dangers on the way. He encounters men who twitter like birds and split themselves in halves; he is imprisoned by a tribe of apes in a crystal palace; he is saved by an army of ants, and ends up in a Jewish town. There he is hired for a strange job: he is asked to hide in a mule skin and be taken by a giant bird to a mountain top, where he has to throw down pre- 
cious stones. From there he wanders on and finds the palace of Sheykh Nașr, the king of the birds, near the Qaf mountain. Here he receives the keys to all the rooms of the palace except one. Janshah nevertheless enters the forbidden room and sees a terrace with a pond and a small palace made of precious stones. Suddenly three birds appear, which take off their robes of feathers and are transformed into beautiful girls who start playing in the pond. Then they put on their coats of feathers and fly away. Janshah, passionately enamoured, hears that the bird-girls are jinniyyas who return every year. After waiting for their return he succeeds in capturing the most beautiful girl by stealing her robe of feathers. The girl agrees to become his wife, and they return to his country to be married and to be reunited with his parents.

On an ominous day Shamsa, his jinniyya wife, recuperates her feathers and flies away, saying to Janshah: 'If you love me as much as I love you, follow me to the gem-castle Takni.' Janshah once again embarks on an adventurous journey, helped by birds and hermits, and after many hardships finds his beloved Shamsa. The couple is married for the second time and decide to spend one year in her palace and one year in Janshah's town. But when resting on one of their journeys, Shamsa goes bathing in the sea and is killed by a shark. Janshah spends his remaining days mourning at her grave. ${ }^{3}$

We can see, even from these brief summaries, how the stories of 'Mirigavati' and 'Janshah' are linked by similar themes and motifs. The story of 'Sayf alMuluk and Badi al-Jamal', too, shows some remarkable resemblances. The story begins with the familiar old king without an heir and an ominous prophecy. As an adolescent, Sayf finds the portrait of a girl in a present given to him by the prophet Solomon. He falls in love and sets out to find his beloved, Badi al-Jamal, the daughter of a jinn-king. After long peregrinations to China and India he is stranded on several islands with demons who sit on his shoulders, man-eating giants, giant apes, and crocodiles, before finally reaching a castle where a beautiful maiden is held captive by a lustful jinn. Sayf kills the jinn by destroying his soul, which is kept in a chest in the ocean, and takes the girl—who is Dawlat Khatun, the foster sister of Badi al-Jamal—with him on a raft. After long wanderings they arrive in India where he is reunited with his friend Sa'id, who was born on the same day as Sayf and who recounts to him his own adventures, especially his escape from a man-eating giant, whom he vanquished by blinding him with a red-hot stick. Subsequently, Sayf is united

3 For summaries and references, see Marzolph and Van Leeuwen, The Arabian Nights Encyclopedia; The Arabian Nights: Tales of 1001 Nights, vol. 2, 390-453; see also Van Leeuwen, The Thousand and One Nights. 
with Badi al-Jamal. However, even before marrying her, he is kidnapped by a jinn. After being rescued he is wedded to his beloved. Dawlat Khatun is married to Sa'id. ${ }^{4}$

All three stories are rich in potential meanings, references, and narrative procedures, but we will first confine ourselves to a discussion of their similarities and their possible interpretations. The first parallel that catches the eye is found on the level of generic characteristics and categories. All three stories are love stories; they are all quests for the beloved one, in the form of adventurous journeys; and they are all related to the succession to the throne of a young king and the perpetuation of the dynasty. The element of prophecy suggests a connection between the destiny of the hero and supernatural forces, strengthening the sense of liminality evoked by the state of the hero as an adolescent and heir to the throne. The hero enters a phase of transition and has to be initiated into the ways of the world, especially the nature of love. After he has conquered his beloved, he has to be reintegrated with his new status into the conventions and institutions of the dynasty. Only then will the dynasty and the empire be preserved. These uncertainties and hazards of the liminal phase are metaphorically shaped by the 'chronotope' of the journey: the hero has to experience dangerous peregrinations to reach his destination and his destiny. These components would typify the stories as love-journeys that constitute a phase of transition for the hero, and would situate them in the category of loveromances. However, the prophecies add another layer to them: it is not only love between two beautiful adolescents that drives the plot; their love is controlled by destiny and linked to supernatural forces. The combination of these elements would situate the three stories in a single generic category, although, as we will see, the ways in which the thematic parallels are elaborated in the narrative itself are different.

The summaries show that 'Mirigavati' contains elements of both 'Sayf' and 'Janshah'. With 'Janshah' it shares the central motifs of the gazelle, as the 'object' that leads the hero astray, creating a desire in him that separates him from his regular environment, apparently as an instrument of fate, together with the, always insecure and confusing, element of water. The second motif is that of the bird-girls, beautiful maidens who bathe in a pond. Raj Kunvar and Janshah both fall in love and conquer their beloveds by stealing their garments, respectively, a sari and a robe of feathers. Subsequently, in both stories the lovers are separated because the girl flies away to her remote homeland, inciting the hero to follow her. The hero then departs on a journey across the seas, which takes him to

4 The Arabian Nights: Tales of 1001 Nights, vol. 3, 95-145. 
a 'castle of birds' where magic birds convene and from where he succeeds in finding the abode of his beloved. Finally, a common motif is the forbidden room, and the inability of the hero to refrain from entering it.

The parallels between 'Mirigavati' and 'Sayf' are to be found mainly in the second half of the stories: the journey and the union of the lovers. A perhaps surprising common motif is that of the Cyclops, which of course brings to mind its counterparts in the Odyssey and in the Oriental traditions, for instance in the Sindbad cycle of the Thousand and one nights and in the Turkic epic Dede Korkut (thirteenth century). The occurrence of this motif here would strengthen the hypothesis of an Oriental origin of the motif of the gobble-eyed or one-eyed, man-eating giant and the escape of the hero in a sheepskin. ${ }^{5} \mathrm{~A}$ second common motif is the kidnapping of the hero after the reunion of the lovers. In both cases it is a vicious jinn/demon that drags the prince away out of revenge or jealousy. Both demons have their souls hidden outside their 'bodies'.

Apart from these motifs, a remarkable parallel lies in the episode of the maiden who is kept prisoner in a castle by a jinn/demon. Both Raj Kunvar and Sayf interrupt their quests to rescue the (human) princess, and Raj Kunvar even marries her, in spite of his search for his true beloved. Although the marriage is not consummated, at the end of the story the prince has two wives, which apparently is not uncommon in romances of this type, as we will see. In 'Sayf' this problem is solved by the sudden appearance of Sa'id, who until then has not played a significant role in the story and seems to have been inserted only to solve the narrative complication of the second unmarried princess. The episode serves only to give Sayf the chance to remedy an injustice and prevent a mismatch between a human princess and a jinn-prince, as an instrument of fate, and to receive a reward for his bravery. ${ }^{6}$

It is clear, that the similarities between 'Mirigavati' and the two Arabic stories are strong enough to surmise a structural relationship between them. But it is the many similarities that make a look at the differences the more interesting. The main difference lies in the manner in which the stories are told. Whereas the stories of 'Sayf' and 'Janshah' are recounted in a rather frugal style, not without humour and sharp observations, but without elaborate descriptions or poetic excursions, 'Mirigavati' is a sophisticated work of poetry, containing

5 James E. Montgomery, 'Al-Sindibad and Polyphemus: Reflections on the Genesis of an Archetype', in: Angelika Neuwirth, Birgit Embaló, Sebastian Günther, and Maher Jarrar, eds., Myths, Historical Archetypes and Symbolic Figures in Arabic Literature: Towards a New Hermeneutic Approach (Stuttgart and Beirut, 1999) 437-466.

6 Richard van Leeuwen, 'De Duizend en één nacht en de Odyssee: een neoplatonistische omzwerving', Stichting Zenobia (Amsterdam, 2014). 
long descriptive passages, both about the beauty of the protagonists and about their passions and hardships. Whereas in the cases of 'Sayf' and 'Janshah' the narrative form is of secondary importance, in 'Mirigavati' the poetic form seems to be just as important as the contents of the story, giving the work as a whole much more balance and coherence. It appears that in 'Sayf' and 'Janshah' the adventure of the journey, with its marvels and wonders, provides the main interest of the story, while in 'Mirigavati' it is the fulfilment of the desire and the union of the two main lovers.

This difference in form and purport of the Indian story and its Arabic counterparts can partly be explained by the Indian concept of rasa, which is the basic structuring principle of the romance as a whole and of romances of this type more generally. The notion of rasa refers to an aesthetic feeling or harmony in which (poetic) beauty, sophistication, sensuality, and emotional fulfilment converge to support both the experience of love and literary appreciation. Thus, the hero - and the author - is not only in search of his beloved, but also of the ideal of rasa, which requires self-sacrifice, courage, endurance, and refinement. The ultimate proof of Raj Kunvar having internalized rasa in his relationship with Mirigavati arrives when he is united with her and has made love to her. The sexual act is described in an imaginative and explicit way, and afterwards Mirigavati brags to her friends about Raj Kunvar's sexual proficiency, which is evidence of the presence of $\mathrm{rasa}^{7}$

In contrast, the stories of 'Janshah' and 'Sayf' seem to be preoccupied mainly with the difficulties of matching humans and jinns, rather than the celebration of their blissful harmony. The story of 'Sayf' begins with Sayf's conception, brought about through a recipe given by the prophet Solomon, suggesting the link between his fate and the realm of the jinns. As a young man he is confronted with the difficult task of leaving the human world and venturing into the world of the jinns to find his beloved. When he has found her, she is doubtful about the possibility of a union between a man and a jinniyya, because humans are unreliable and unfaithful. Her grandmother, too, is sceptical, and it is remarkable that Sayf and Badi's marriage is not confirmed by witnesses and a contract, as is the marriage of Sa'id and Dawlat Khatun. In 'Janshah', too, the thematic emphasis seems to be on the incompatibility of humans and jinns. There is a clear separation of the two domains, guarded by boundaries and taboos, and by unimaginable distances and strange lands, and in the end the union is broken by the violent death of Shamsa.

7 This interpretation of the story is based mainly on Aditya Behl, Love's Subtle Magic. An Indian Islamic Literary Tradition, 1379-1545, Wendy Doniger, ed. (Oxford, 2012). 


\section{Sufis and Solomon}

In his monograph about the four Hindavi romances, 'Mirigavati', 'Madhumalatì', 'Padmavati' and 'Candayan', Aditya Behl tries to clarify both the potential meanings and the cultural-literary contexts of the texts. His hypothesis is that the authors were mystic poets who participated in the revival of Sufism in the fifteenth and sixteenth centuries during the rise of the Mughal sultans. According to Behl, the challenge of these poets was 'to make their spiritual agenda comprehensible and appealing in an Indian cultural landscape, using local terms, symbols, techniques, and gods.'8 This challenge was taken on, first, by applying a surprising measure of syncretism, such as we have seen in Hang Tuah and Les 32 marches du trône. It is remarkable for an Islamic text to contain heroes with Hindi names and references to Indian literary works such as the Ramayana and Mahabharata, and even holy texts such as the Rig Veda. Although Muhammad and the one God are mentioned, an appeal is made to Gods of the Hindu pantheon, including Indra, 'the king of the Gods'. ${ }^{9}$ In addition, the Sanskrit concept of rasa, the personage of the yogi, and the selfimmolation of women are crucial elements in the story taken from Hindu traditions.

A second strategy of the Sufi poets, according to Behl, is to use the Hindavi language and elements of popular folklore to construct a love story that fits into the local worldview. The element of the quest for the beloved, of course, allows for adventures, passion, and, above all, a trajectory and an initiation that structure the story on various levels. The journey inaugurates a state of liminality for the hero, preparing his tumultuous encounter with the world, disguised as a yogi, and pushing him forward to his initiation into love and the fulfilment of his desire. This form would not only conform to Indian popular tales and satisfy local literary tastes; it can also function as a symbolic representation of the Sufi message that it contains: the quest of the hero for mystical insight and spiritual experience. The story is thus an allegory using religious syncretism and the associative force of the love story to convey a coherent mystical message.

The different levels of meaning in the story can also explain the rather odd combination of the two marriages of the hero. According to Behl, Mirigavati is a semi-divine figure, a magical creature, taking on the shape of a doe, and capable of assuming all shapes. She symbolizes the divine presence that is the ultimate aim of the Sufi. Rupmini, in contrast, is an ordinary human princess,

8 Ibid., 1.

9 Ibid., 117, 122. 


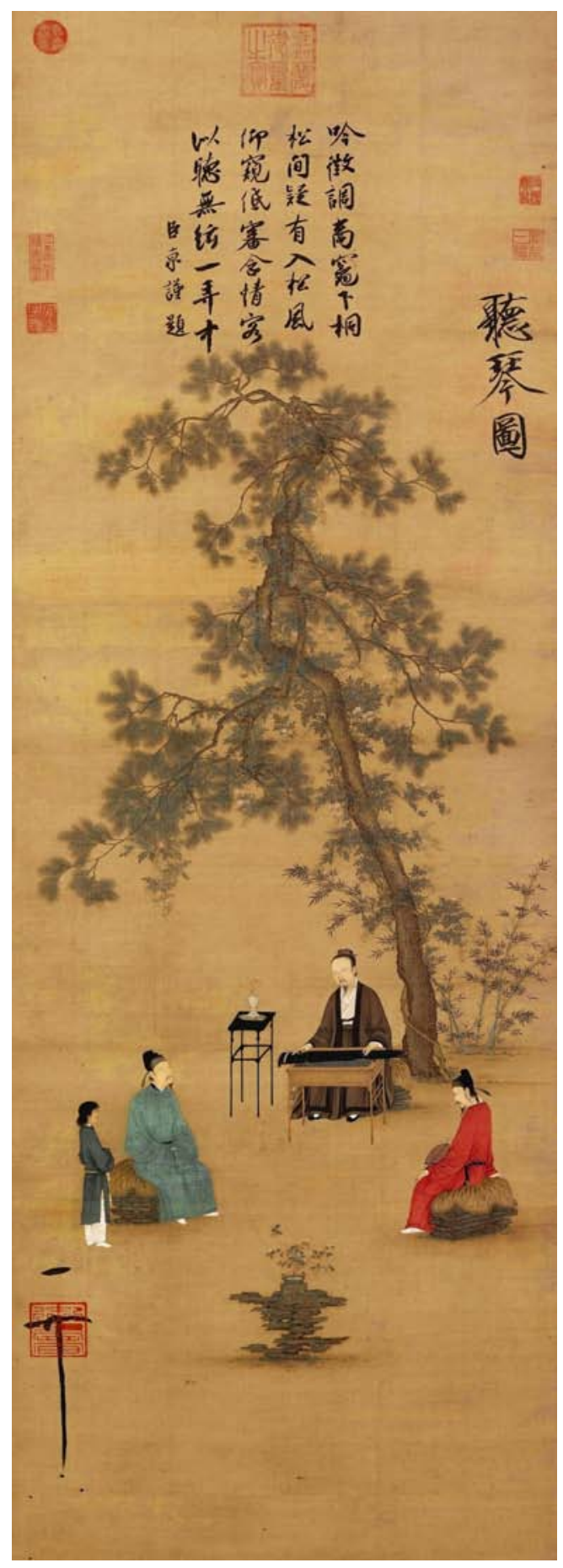

FIGURE 8

Emperor Huizong, Listening to the Qin, China, ca. nth century. 
representing the earthly domain, material possessions, and worldly pleasures. She is rescued by Raj Kunvar, but then relinquished in favour of Mirigavati. She represents merely a stage in Raj Kunvar's trajectory, and he returns to her only after having found Mirigavati, taking his marital rights by force after having abstained from her previously. Thus, apparently, rasa can be truly achieved, for a human being, only by amalgamating with the divine presence. The state of rasa is spiritual, a unio mystica, which is here followed by Raj Kunvar's death, which, according to Behl, is the mystical loss of the self, or fanä.10

The mystical level of meaning that Behl observes in the romance of 'Mirigavati' appears to contrast sharply with the apparent non-allegorical purport of 'Sayf' and 'Janshah'. Here the quest for the beloved is the aim of the journey, but, as has been said above, this quest is quite explicitly linked to the forces of fate, by the interpenetration of the domains of the human and supernatural worlds. The central structuring element in both stories is the figure of King Solomon. In 'Sayf' this is clear from the beginning, since Sayf's father consults Solomon about how to beget a heir and Sayf receives a garment with the image of Badi al-Jamal from Solomon. Thus, from the onset the boundary between the human and supernatural realms is clearly permeable. Nevertheless, if the passion of Sayf is perhaps incited by fate, it is also based on a mistake, since Badi al-Jamal's mother had given the garment to Solomon in an effort to arrange a marriage between him and her daughter.

The crossing of the boundary between the two realms is therefore both irregular and decreed by fate. The irregularity is mirrored in the episode of Dawlat Khatun, a human princess, and the jinn prince. This is a clear mismatch, which is set straight by Sayf and ultimately leads him to his beloved Badi alJamal. Even then, when Sayf is united with Badi al-Jamal and both profess their love, the question of the compatibility of the two species is discussed, turning it into one of the main themes of the story. In a similar way, in 'Janshah', too, Solomon is one of the main structuring elements. Janshah crosses a boundary when he enters the palace of the jinniyyas and opens the forbidden door. His journeys are marked by signs from Solomon, indicating that he wanders through a supernatural realm, governed by Solomon and his helpers. Here, too, the ultimate question is whether the union between a jinniyya and a human man is possible, however passionate their love may be.

If we compare these interpretations of the three stories, it is clear that they are all concerned with the exploration of forms of esoteric knowledge, a conclusion strengthened by the incorporation of the story of 'Janshah' into 
the cycle of the 'Queen of the Serpents' in the Thousand and one nights, an eschatological cycle including material related to the qișaș al-anbiya, or vitae prophetorum (see Chapter Three), and by the story framing the story of 'Sayf', in which it is related how the story was found and which contains the warning that it should not be told to an ignorant audience. However, although the theme of initiation is similar, the elaboration of the esoteric theme is completely different, Janshah and Sayf associating the esoteric knowledge to the realm of Solomon and the jinn, the qișas al-anbiya and the segment of creation that contains the mechanisms through which Solomon regulates the natural forces, while in 'Mirigavati' it is the realm of the Divine that is sought, albeit symbolically, and a mystical state only symbolized by sexuality and love. Raj Kunvar's journey is a moral trajectory rather than an exploration of the world of the unseen. Because 'Mirigavati' is a symbolic story, it would, in spite of all the resemblances, belong to a quite different genre than 'Sayf' and 'Janshah'. Apparently the authors, using the same narrative material, aimed to represent different domains of the religio-cultural tradition.

The relationship between the three stories studied here is buttressed by a second Sufi romance, titled 'Madhumalati' and written by Sheykh Mir Sayyid Manjhan Rajgiri of the Shattari order in 1545. This story contains several motifs also found in the story of 'Qamar al-Zaman and Budur' in the Thousand and one nights, ${ }^{11}$ affirming the link between the two corpuses of narrative material. Starting with the familiar motifs of the absent heir and the prophecy about the fate of the newly born prince, the story continues as a love story. The prince and his beloved are brought together by two flying nymphs, and after their encounter they exchange rings before being transported back home. The prince, finding the ring when he wakes up, embarks on his quest, dressed as a yogi, meeting on his way a princess who has been captured by a demon. After killing the demon by cutting a tree containing its source of life, he takes the princess with him, without marrying her, until he finds his true beloved. These motifs resemble, in particular, the stories of 'Qamar al-Zaman' and 'Sayf al-Muluk', and here, as in the latter story, a second prince is staged quite unexpectedly to marry the spurned princess. Other parallel motifs are the pavilion with paintings revealing the state of mind of the beloved, and the fowler who captures Madhumalati after she has been transformed into a bird. It is noteworthy that the story of 'Qamar al-Zaman' ends with the hero being married to two wives, like Raj Kunvar and similar to the second-princess motif in 'Sayf' and 'Madhumalati', an anomaly that can be solved only by attaching 
a sequel, the story of 'As'ad and Amjad'. In this case, too, there is a difference in genre: whereas 'Madhumalati' is a Sufi allegory, according to Behl, 'Qamar al-Zaman' is an unmitigated love story.

The intriguing question, after these brief comparisons, is, of course, how we should evaluate the strong connections between these stories. Is it possible to establish the nature of their relationship? Is it possible to situate them within a single cultural, historical, literary framework? In his study of the corpus, Aditya Behl tries to reconstruct the framework in which the transmission of this material can be understood and explained. However, his analysis remains somewhat vague. On the one hand, he argues, mainly by discussing the Cyclops motif in the 'Sindbad' cycle and the 'Mirigavati', that apparently a lot of interaction took place between the Indian subcontinent and the wider Islamicate world, especially Persia and the Arabic west. In the case of 'Sindbad' he surmises the influence of the story of 'Sanudasa the merchant', a Sanskrit cycle of travel and love of the fourth century. In the case of the romances, however, he rather sees the reworking of Arabic material, combined with elements taken from Persian love romances and local folklore.

This analysis does not seem very satisfactory. First, we need a much stronger and more precise historical framework to prove and reconstruct the transmission of narrative material, for instance by presupposing a cultural and intellectual exchange in the wake of the expedition of Timur Lang, in the fifteenth century, or by the intensification of trade contacts in Mamluk times or the migration of Sufi brotherhoods. Second, although influence from Persian sources is probable, particularly with regard to the masnavi form of the romances and the name 'Janshah' in the Arabic story, there are no direct Persian models extant for these specific stories. It seems too easy to suppose a 'Persian link' in the transmission of this material, if it cannot be determined what this link consisted of more precisely. Still, the possibility of a Persian link looks promising and has the merit of placing the process of transmission in a wider context. In an article about the Asian traditions of 'Sayf al-Muluk', Christopher Shackle complains that stories of this type in Asian languages are too readily ascribed to the Thousand and one nights as a kind of universal source of narrative material. He points out that the Sayf al-Muluk tradition goes back a long time before the story was incorporated into the Nights and defines it as a typically Persian romance. However, the various manuscripts to which he refers all date back to the seventeenth to nineteenth centuries, so whereas they could be a source for the Arabic version in the Thousand and one nights, they are too late to have served as a model for 'Mirigavati'. Of course, it is possible that Persian versions that have not been preserved circulated in India at an earlier date. The earliest texts that Shackle mentions are a Chagatay version from the sixteenth cen- 
tury, by the poet Meclisi/Majlisī, and an Urdu version by the Golconda poet Ghawwās datable to 1625 . Both are mathnawì poems.

Whereas apparently the evidence for the Persian tradition of 'Sayf al-Muluk' is of a rather late date, the Chagatay reworking of the story points to a Turkish component in the development of this kind of narrative material. This is confirmed by the occurrence of the motif of the bird-girl and the Cyclops-figure in the Turkish epic Dede Korkut. Delio Proverbio has discovered manuscripts of 'Sayf' dated as far back as the fourteenth, perhaps even the thirteenth century in Ottoman Turkish, in addition to a mathnawī version by Luṭ̂i from 1456 . The latter text was part of a collection called Fereç ba'd eş-Šidde that originated in the second half of the fourteenth century. Remarkably, an Ottoman version of a work with the same title was the origin of the first versions of the story in Europe, through the publication of French translations by Pétis de la Croix (1710-1712) and especially Comte de Caylus (1743). There is also an Ottoman translation of the story of 'Janshah' that dates back to 1429, incorporated in the cycle of the 'Queen of the Serpents.'12 The manuscripts referred to above give evidence of a rich narrative tradition in which Persian, Turkish, Urdu, and Indian literatures intertwined, and which ultimately spread to Europe.

If we go back to our three main stories, some indications can perhaps be derived from the differences within the texts themselves. Is there internal evidence to suggest that one of the stories is the oldest version that has served as a model for the others? If we compare the narrative form and structure of the stories, the first impression is that the Indian romances are much more accomplished as literary works. They are more elaborated, more consistent, and more sophisticated than their Arabic counterparts. What is lacking in the Arabic stories is particularly an overall cultural-literary concept, unifying meaning and form, which is represented in the Indian romances as rasa. It may be that the Arabic stories were a more primitive version and that the idea of rasa was added by the Indian poet, to secure the allegorical meaning of the narrative, but it may also be that the Arabic author chose to eliminate it as an alien element. He may even have missed the implicit Sufi message of the romance, merely using its material to compile a new story with a more explicit esoteric dimension.

The omission of the concept of rasa affects the narrative consistency of the story of 'Janshah'. After all, in 'Janshah' it is not explained why Shamsa, after her union with Janshah, leaves him to go back to her parents. The reader has to guess that it is probably because of her fickle nature as a jinn, or because 
she refuses to comply with his forceful way of capturing her. In 'Mirigavati' this reaction is made explicit by Mirigavati herself, who says that his capturing her by force is incompatible with the principle of rasa, which is the only true basis of love, and, of course, of harmony with the Divine. Thus it would seem that the Arabic author left a narrative gap in the story by cutting the rasa-element and refusing to find a way to restore the consistency of the story. On the other hand, the motif of the two wives of Raj Kunvar is from a narrative perspective not very conveniently solved. It may be that the two princesses represent worldly and divine interests, but it would appear that it is more elegantly solved in 'Sayf' by introducing a, perhaps too convenient, second suitor. This is also the solution chosen by Manjhan in his 'Madhumalati'.

Now what do these stories, and the connections between them, tell us about discourses of kingship? First, their obvious relationship reveals that they pertain to a single cultural realm, which contains elements from the Indian, Persian, Arabic, and Turkish traditions. This suggests the existence of a common cultural substratum, founded on narrative texts, on which visions of kingship and authority were built. This realm was not static, of course, since it was upheld by infrastructures of exchange, trade, migration, military campaigns, and written texts. Second, within this realm we find differentiations, in taste, style, concepts, and interpretations. Whereas in some cases literary texts are 'officially' translated, more generally they were deconstructed and reconstituted in other ways, serving the tastes and inclinations of their new environments. It is especially in this fluidity and changeability that the role of literature as expression of the collective imagination comes to the fore. And within these processes of transmission and proliferation, love stories assume a prominent, perhaps even the most prominent, role.

If we look at the formal aspects of the romances analysed above, we find that, like the romances of chivalry, they are structured mainly by the 'adventure trope. The prince reaches a marriageable age, falls in love, and sets out on a journey to find his beloved, conquering all kinds of obstacles on the way. After he has won the heart of his princess, he is legally married to her and returns to his home palace to succeed his father as king. The pattern resembles that of the chivalric romance: the king reaches old age and the dynasty is in danger of coming to an end; the prince goes out into the world to be initiated into the vicissitudes of life and, of course, the entanglements of love, and returns as an adult man, versed in life's perfidy, acknowledged as a hero, and provided with 'booty' in the form of a lovely spouse. This rather rigid pattern indicates that the prince and the other characters do not have much space to act freely, but just have to perform their prescribed roles. They are flat, emblematic, characters, created only to perpetuate the dynastic cycle as is predestined by fate. 
This outline of a rather schematic narrative structure suggests that these stories have limited potential of interpretive interest. The element that provides them with narrative possibilities is, of course, the theme of love. Love not only adds a dramatic plot to the story, creating narrative tension, deferral, and a structural and metaphorical matrix; it also builds inside the story the 'feminine' paradox of interruption - through the dangers of passion — and the necessity of procreation - through sexuality. The element of love, which is unpredictable and difficult to control, requires a breaking up of the cycle of dynastic power, a liminal period of quest and adventure, in order to bring about a restoration of the previous equilibrium. This pattern is imposed by fate, but it is also linked to a specific person, whose love is directed at another specific individual, thereby linking the collective destiny of the community to the destiny of a specific individual, legitimizing his claims to power and kingship in the end. The pattern prescribes this alternation with socially pre-established roles and periods of interruption and individual growth to achieve harmony when the desire of the prince for his beloved is stilled and contained within the framework of law, social conventions, and dynastic interests.

Just like war, the theme of love enables the narrator to instil all kinds of moral capacities in his characters. The hero is courageous, smart, inventive, just, gallant, compassionate, etc., while the heroine is chaste, obedient, convinced of her passion, beautiful, sophisticated, and resourceful. But unlike the theme of war, love creates space within the narrative to include all kinds of aesthetic and imaginative elements in the story, because love is connected with beauty, sophistication, emotions, happiness and grief, idyllic environments, wonder, intoxication, eroticism, delicacy, tenderness, enchantment, etc., allowing the narrator to imbue the story with a vast array of symbolic and imagined references related to the liminal state of passion. This is not merely intended to embellish the story, of course; it is also part of the education and personality of the prince, who should incorporate these aesthetic values and sensibilities in his performance of kingship. In the various stories this dimension is incorporated in different ways, as the concept of rasa or as the experience of wondrous, labyrinthine worlds.

The love romance thus consists essentially of a basic pattern that allows for the insertion of an element of contingency and narrative liminality, which produces the dialogical complexity of the discourse of kingship, as constituted by the confrontation between feminine and masculine elements. Often, in stories of this kind, there are advisers, too, who act as intermediaries between the conventions and the swerving prince. As we will see presently, similar patterns can be found in European narratives of kingship and love. 


\section{The Enchantment of Love: European Fantasies of Kingship and Love}

When Cervantes in his Don Quijote predicted the demise of the chivalric romance and fostered the taste of realism in literature, he aimed not at the old chivalric cycles, but at the revival of romances in Europe in his time. After the era of the great medieval cycles had come to a close, interest in romances of chivalry revived at the end of the fifteenth century and the beginning of the sixteenth, especially through the popularity of the cycles of Amadis de Gaule and, somewhat later, Palmerin de Oliva. Spain, in particular, became the cradle of new adventure stories, perhaps under the influence of the important romances of Cifar (late thirteenth century) and Tirant. The revival of interest coincided with a renewed popularity of the practice of chivalry, probably engendered by the military events of the period, particularly the conquest of Constantinople by the Turks in 1453 and the conquest of Granada by the Spanish kings in 1492. The chivalrous ideal was invested with a new 'ennobling spirit', a new conception of love, 'embodying the protest of a more moral and religious age against the frenzied or adulterous passion of the Celtic stories. [...] Love is depicted as a lasting adoration; the adored one-and, through her, woman in general-is idealized and made the centre of a new social order, devoted to the service of womanhood.13

In the neo-chivalric romances the emphasis was laid on love-intrigues rather than on martial values and the moral impact of the struggle against the infidels. This latter element did not disappear, however, and also the basic adventure pattern was retained. In general, the stories are quite schematic, involving an avalanche of characters all involved with each other through family or love ties, abducted ladies, struggles against giants, misunderstandings, miraculous escapes, and endless journeys across the Mediterranean, from Spain to Constantinople, to Egypt, to Cyprus, to England, and back. Supernatural forces hide everywhere to make ships drift off their intended course or otherwise change the destinies of the heroes. In the end, all characters destined for each other are married, not only to close one episode of the cycle, but also to produce sons and daughters for the next episode in which the adventures are more or less repeated.

Stories of this kind were immensely popular throughout Europe and were translated into the main European languages and usually also adapted to local tastes. They were read and praised first of all at the European courts, but

13 Henry Thomas, Spanish and Portuguese Romances of Chivalry (Cambridge etc., 1920) 49. 
evidence suggests that the common people relished them as well. They were also frowned upon, however, for their promulgation of a rather gratuitous spirit of adventure and their erotic licentiousness. Contemporary critics called them the 'ulcer of the bookshelves' and 'books that corrupt chastity'. Such books, which 'destroy the young', should 'be consigned to the flames, or banished to Sicily, where men are used to wasting themselves in continual watch and ward against the nightly marauder and the matrimonial bandit.'14 They were considered a 'develish art, written by Mohammedans', who were 'experts in black magic' and spread poison through pleasant stories. ${ }^{15}$

The neo-chivalric romances thrive on an explicit insertion of exoticism, in the geographical sense - the Eastern parts of the Mediterranean - as well as in the sense of including all kinds of magical interventions to lead the heroes astray or to help them achieve their aims. As in the so-called Popular Books, such as Fortunatus, the Pierre de Provence novels and others, the Orient contains a fascination that is exploited to complicate the hunt for the beloved. A good example of the tendencies in this period is Margaret Tyler's Mirror of princely deeds and knighthood, which appeared in 1578 . The work was a translation and reworking of a Spanish original, but it was adapted to the English-Protestant - taste. The story is about Trebatio, the mighty king of Constantinople, who, on hearsay, falls in love with the daughter of the king of Hungary, Brianca. She has been promised to the English Prince Edward, however, so that Trebatio has to kill Edward and impersonate him to seduce Brianca. He begets two sons by her. Subsequently, and rather strangely, Trebatio is magically led to an enchanted castle on a Mediterranean island, where he indulges in passionate pleasures with a mysterious princess. The actual story is about the adventures of his two sons, until he is 'rescued' from his enchantment twenty years later.

The narrative consists of a familiar sequence of plots and motifs, ranging from abduction, miraculous turns, magic boats, talismans, tournaments, ladies in distress, misunderstandings, martial exploits, pagans and Persians, hairy giants, soothsayers, pirates, shipwreck, cross-cultural encounters, and, finally, reunions and re-separations. More interesting perhaps than the story itself is the circumstance that the work was translated and adapted by a woman, and not as usually by a, mostly anonymous, man. Narratives of this kind were generally deemed more harmful to women than to men, since they might inspire chambermaids to set out as a 'lady errant'. Interesting, too, are the

\footnotetext{
14 Ibid., 228-229.

15 Ibid., 231.
} 
adaptations made to render the text more palatable for the English readers. The main interventions are meant to suppress the many marvellous instances, which were associated with the exuberant imagination of Catholicism. The Mirror reflects a 'deep suspicion of the marvellous that is consonant with the Protestant poetics conveyed in anti-Papist texts and in the romances of her Reformed contemporaries.'16 Papists were accused of being engaged in 'conjurations, magical artes, false miracles, lying wonders, deceivable sines, malitious devises.'17 To counter this evil, Tyler replaced the word 'marvel' and cut out most references to supernatural phenomena. Still, some 'marvellous' elements were maintained, such as the enchanted castle and the giants representing the uncivilized barbarians. A certain admiration for the 'Saracen' Other is preserved from the Spanish original, based on a universal conception of chivalric values, although conversion is obligatory to restore a form of moral harmony.

One of the interesting aspects of the Mirror is that it links the indigenous, English, tradition of knighthood with the great centre of Christian authority, Constantinople, a polarity also found in Tirant lo Blanc. In another example of the neo-chivalric revival in the sixteenth century we can see how this kind of exoticism is used not so much to describe an encounter between components of a single realm, or with a common Other, but rather to project moral/political issues into a foreign environment. This text is especially interesting for our discussion since it is rather ambiguous generically: It is a mixture between a mirror for princes and a romance of chivalry. It combines an examination of love with a search for the principles of rulership. Such ambiguity allows Barnaby Riche's The adventures of Brusanus, prince of Hungaria, printed in 1592, to convey the literary conventions of its time, but the work also stands out for its innovative methods. As a result of its narrative hybridity, combining diverse elements, it introduces some techniques that herald future conventions in European literature, such as internal contemplation. In spite of its rather unbalanced complexity, it enjoyed considerable success among the contemporary audience.

The story of Brusanus is situated in the time of Libernis, the king of Constantinople, ruling over Cairo, Syria, Calipha (Baghdad?), and Greece, 'in the most Christian and Catholic faith. ${ }^{18}$ King Myletto of Hungaria has a son named

16 Margaret Tyler, Mirror of Princely Deeds and Knighthood, Joyce Boro, ed., M HRA Tudor and Stuart Translations, vol. 11 (London, 2014) 'Introduction', 6.

17 Ibid., 10.

18 Barnabe Riche, The Adventures of Brusanus, Prince of Hungaria (1592), Joseph Khoury, ed. (Toronto, 2014) 127. 
Brusanus and a daughter named Leonida. Brusanus is handsome and well built, but voluptuous and full of 'wantonness, licentiousness, wilfulness and wickedness': 'neither the fear of God, the displeasure of his parents, the sundry admonitions of his careful and loving friends, nor the regard of his own honour could make him desist or drive him from his detestable kind of life. ${ }^{19} \mathrm{He}$ indulges in gambling, swearing, swashing, masking, mumming, dancing, banqueting, and boozing. His father, worried, cuts his allowance and exhorts him to mend his ways. After all, one day he will be a king, and such an illustrious position requires virtue and honour. A king should enrich his subjects, spare the honour of women, let himself be admonished, be loved by the people, trust his subjects, keep taxes low, have recourse to his subjects in war, be honoured during his life, strive for the welfare of the community, account for himself, and be disciplined as an example to others. Common wisdom says: 'A cruel prince will make a slaughterhouse of his commonwealth, a whoremaster will make it a stews; a prodigal will suck the marrow of his subjects to glut some halfdozen flattering parasites that will be about his person disguised in the habit of fidelity.'20

However, after this clear warning, the situation deteriorates, and the king prohibits all loans and gifts to his son. The friends who had partaken in his squandering now forsake him. His mistress, in particular, refuses to help him, and Brusanus, disillusioned, damns all women and sex. In order to pursue virtue, he sets out on an 'educational' journey. In Epirus, the neighbouring empire, King Leonarchus is loved and respected, because of his 'justice, liberality, mediocrity, peaceable government, gravity and authority. ${ }^{21}$ However, since he is roaming the kingdom to inspect the conditions of the subjects, dressed as a merchant, he has been missing for some time, and the people ask his noble son Dorestus to ascend the throne. Brusanus, also incognito, joins the king and two others go to the court to complain about a case of corruption. Dorestus hears the case and judges 'with mediocrity that neither we lean to over much severity, nor yet may be led by too much lenity.'22

After Brusanus and Dorestus have become friends, the latter summarizes the principles of good government: "The office of a good prince is to defend the commonwealth, to help the innocent, to aid the simple, to correct the offender, to relieve the poor, to honour the virtuous, to punish the vicious, to bridle the

\footnotetext{
19 Ibid., 128.

$20 \quad$ Ibid., 131.

21 Ibid., 142.

22 Ibid., 162.
} 
ambitious, and by justice give every one his own. ${ }^{23}$ Now Leonarchus throws off his disguise and reports about the situation of the kingdom, which is full of vices, as he has witnessed with his own eyes: Men are idle and not well occupied; usury, extortion, and hoarding are widespread, people are subject to pride and ambition, and practice simony. Oppression, malice, and lack of love reign everywhere.

After celebrations and a tournament in which Brusanus distinguishes himself, using the sign Invidia amoris, or 'Hatred of love', Brusanus and Dorestus travel together to Illyria, which is ruled by the cruel tyrant Astulpho. Now an intricate love-intrigue ensues: Dorestus falls in love with Astulpho's daughter Moderna, who, however, becomes enamoured of Brusanus. A dispute between the two princes follows, in which Brusanus warns his friend against the pitfalls of love: 'His associates and chiefest companions are pain, travail, anger, rage, fury, doubt, grief, languish, threatening despair, uncertain hope; his surest good a certain base weakness; his truth are labour, some adventures, nay, rather loathsome misadventures, which either will bring forth ill success or no success. ${ }^{24}$ Dorestus is not convinced, however, and, spurred on by his passion, he retorts:

Love is a god and will be obeyed, and looks to command, not to be conquered; and beauty cannot be resisted. Dare reason abide the brunt where beauty bids the battle? Can wisdom win the field where love commands as captain? O no, no! Love is without law and therefore above all law; honoured in heaven, feared in earth, and a very terror to infernal ghosts. ${ }^{25}$

In his bitterness, Brusanus describes love as lewd, lascivious, beastly, and odious, and as a 'loadstone to ruth and ruin.' ${ }^{26}$ Beauty can be dangerous, as in a tiger or a snake.

Dorestus does not share Brusanus's aversion to women: 'I cannot so lightly be induced to mislike of that sex of whom I was born, of whom I received life, by whom I have been nursed and charily brought up. And women are framed of nature with as great perfectness of the mind for the exercise of virtue as man.'27 And he adds:

$\begin{array}{ll}23 & \text { Ibid., } 174 . \\ 24 & \text { Ibid., 199. } \\ 25 & \text { Ibid., 200. } \\ 26 & \text { Ibid. } \\ 27 & \text { Ibid., 203. }\end{array}$


Had not nature adorned them with perfection of beauty, delicacy of body, excellency of wit, and such sweetness in all their demeanours that men of any judgement and able to discern of such inestimable riches, do they not whet their wits, their wills, their tongues and all their whole inventions how to comprehend their favour and insinuate themselves into their grace? ${ }^{28}$

In the meantime, Dorestus reveals his love to Moderna, who rejects him, however, in spite of her father's insistence that she marry him.

Moderna, in turn approaches Brusanus, who, to her grief, turns her down with the spiteful words: 'Madam, when dogs fall to snarling, serpents to hissing, and women to weeping, the one means to bite, the other to sting, and the third to deceive. [...] I have no leisure to love, I must about other business.'29 This is not the end of the affair, however; the dispute continues in the erudite references to the opinions on women of the ancient philosophers Marcus Aurelius, Seneca, Diogenes, Plutarchus, Protogenes, Plato, Pythagoras, Aristotle, Socrates, Chilon, and Tertullian. Brusanus argues that love turns a wise man into a fool, a religious man into an idolater, an honoured man into a scorned man; it makes a careful man negligent, a valiant man weak, a provident man careless, a young man withered, a rich man poor, and a patient man revengeful. These exchanges about the nature of women and love gradually persuade Brusanus that his reluctance to love is erroneous, and Brusanus and Moderna, rather abruptly, decide to elope together, leaving Dorestus 'in a brown study',30 that is, in despair.

The couple escape to Greece and from there to Calipha, where they are cruelly separated by fate, and Brusanus becomes involved in treacherous palace intrigues. These intrigues are added to the trail of anger and resentfulness that Brusanus has left behind, and that causes several kings and princes to mobilize their troops and attack each other to rectify the abuses of the prince. In the turmoil Brusanus shows himself a courageous, just, and clever warrior, defeating the evildoers, unravelling vicious schemes, gallantly defending ladies, and supporting the righteous kings. In the end he is reunited with Moderna. Dorestus, however, is still immersed in bitterness: "Then he called to his mind how Moderna had despised him, and here he began with disdainful imaginations to condemn all women of instability, of inconsistency, of lightness, of uncertainty,

$\begin{array}{ll}28 & \text { Ibid., 205. } \\ 29 & \text { Ibid., 229. } \\ 30 & \text { Ibid., 244. }\end{array}$


and to accuse them as creatures that were vowed to all manner of vanity. ${ }^{31}$ Fortunately, he falls in love with Leonida, Brusanus's sister. After the marriages have taken place, Dorestus says with relief: 'O Brusanus, I can but rejoice to think that the enemy to all woman-kind is yet at length become a sworn soldier in the band of Cupid and contented to march under the banner of Venus. I hope by this time you have renounced all your former heresies. ${ }^{32}$

In this summary we can easily discover some basic pattern, springing from an intrigue linked to the interruption of the dynastic succession and the intervention of a treacherous concubine. We encounter familiar tropes, such as the parallel figure of the friend/rival, the prevailing of love, and the sequence of comic intrigues leading to a final denouement. We see the hero crossing a cultural boundary and entering a wasps' nest of conspiracies, honest ladies supporting trustworthy men, the hero protecting ladies in distress, the intervention of fate in the guise of brigands, etc. Still, in spite of this schematic structure, the story is not completely emblematic. This is due, first, to the development of the hero, who completes a process of psychological maturation, and, second, because of the explicit contemplations about statesmanship and love, and, more significantly, about the connection between the two. This interpretive potential is made possible by the generic ambiguity of the narrative, combining a love adventure with components of a mirror-for-princes type.

The trajectory of Brusanus is made more charged as a result of some ironies built into the dialogical structure of the story. At first, Brusanus is deaf to the good advice of his father and gives up his wanton life only when he is forced to do so. When he is confronted with true love, he is deaf to the arguments of Dorestus, who experiences the power of love. In the end Dorestus convinces Brusanus of the positive side of love to his own detriment, and later it is Brusanus who has difficulty in persuading Dorestus to give up his misogyny. As in other texts, the story is based on a dialogical situation, which isalmost - two-sided and which succeeds in producing harmony. The dialogic situation is found, too, in the episode at the court of Leonarchus, where ideas are exchanged about proper rulership. All these considerations become pertinent only when they leave the realm of words and penetrate into the realm of experience.

In order to abandon his obtuseness, Brusanus has to experience love and be confronted with the abuse of power. He has not only to be initiated; he must prove as well that he is a worthy prince ready to stand up against injustice

31 Ibid., 296.

32 Ibid., 325 . 
and oppression. Only when he has completed this trajectory, when he has internalized the values of the good prince, has he sufficiently matured to occupy the throne. This is not only an initiation into the art of statecraft; it is also a process of personal growth, since Brusanus has to forsake his former manners and learn to behave according to moral standards. First of all, he has to contain his lust, not by excluding women from his life, but by finding the balance between love and lust. As the prince of Calipha rightly observes: 'The greatest conquerors be they that can conquer themselves, and honour is soonest ministered to him which can manage his own affections.' ${ }^{33}$

As remarked above, the discursive complexity of Brusanus is integrated into its form. It contains letters and personal reflections that break the sequence of events and insert 'dialogues' that postpone the actual story. The dialogues create different levels within the story, to the effect that the story is not just propelled by a series of subsequent events, but that part of the narrative dynamic is produced by contemplation and psychological transformation. They create a space within the story in which events can be seen from a different perspective, enabling a change of the interpretation of these events within the narrative context. The growth to kingship does not consist of a rather mechanical process of collecting experiences, showing capabilities, and conquering a beloved; it is also a process of inner growth and deliberation, combining experience with abstract principles. As in other stories, it is the many sides of love and sexuality, and their embeddedness in culture and society, that are the catalysts instigating the dialogue and the events that in the end together reveal the true nature of kingship.

This still rather tentative narrative complexity will remain significant in European literature, especially during the seventeenth and eighteenth centuries, when writers were almost permanently struggling and experimenting with literary form. These experiments were induced partly by the necessity to deal with a new political environment in which the unbound imagination of the romances collided with political realities in its preferred realm, the Eastern Mediterranean. The fantastic nature of the romances was systematically associated with the Orient-by Cervantes and others-creating a discursive break in what seemed to be the essence of fiction - the imagination - and the reality of cultural and political boundaries. If the Orient as a source of literary inspiration could not be excluded, at least it necessitated a redefinition of its purport. What is more, in the seventeenth and eighteenth centuries the Orient was no longer the domain of unrestrained fantasies; it became a place as 
'real' as Europe itself, a source of knowledge and wisdom, and part of the same scientific reality that Europe identified with. Thus, while reality became more homogeneous, it became more complex, too, and the straightforward narratives of the sixteenth century were insufficient to cope with the new visions of the world that imposed themselves.

There are several texts that exemplify this process. Here we will confine ourselves to discussing one example, showing how the Orient still served as a narrative focus and textual complexity heralded the novelistic form: Madame de Lafayette's novel Zaïde, which appeared in 1671 . The novel clearly shows some lingering characteristics of the chivalric romance, which has now developed into what is usually called a histoire galante, a love story combined with elements of adventure. Like the earlier romances, the histoires galantes are also constructed around the cultural-political boundary between Christianity and Islam, more specifically the Ottoman Turks. However, they mark the transition from emblematic to increasingly personal stories focused more on individual experiences and psychological inquiry, at least in some of the representative works. The heroes and heroines are no longer mere vehicles for a schematic story; they carry their personal dilemmas and are responsible for their acts. This development became more pronounced in the literature of the eighteenth century.

The story of Zaïde seems to be a response to the momentous fall of Granada under the attacks of the Catholic kings in 1492. It is set, however, in the kingdom of Leon in the ninth or tenth century, when the outcome of the struggle against the Muslims was still undecided. One of the innovative aspects of the novel, adding to its narrative complexity, is that it begins in medias res, with Consalve, the handsome and trustworthy son of a Castilian count, leaving the royal court of Leon and joining Alphonse, the son of a prestigious Navarrese family who has retired in a small cottage on the Mediterranean coast. Hoping to find solitude, Consalve's peace of mind is disturbed when a small boat is thrown up on the shore, depositing a lady of exquisite beauty, clad in a lovely, though somewhat exotic, garments and accompanied by a servant. Consalve tries to speak to her to find out who she is, using Spanish, Italian, and Arabic, but she seems to know none of these languages, although she has Moorish features.

In an interruption of the main story, Consalve now confides his identity to Alphonse and explains what made him flee his distinguished home. His father is one of the most powerful counts, whose might is feared even by the king. Consalve was befriended by Crown Prince Don Garcie. He fell in love with one of the court ladies, Nugna Bella, but the king cannot endorse a marriage between them, because this would imply a union between the two mightiest families of the kingdom. What is more, Don Garcie expresses his interest in Consalve's 
sister, which leads to enmity between the two friends, since Consalve is suspicious of the prince's intentions. In the meantime, political intrigues result in Consalve's father's estrangement from the king, while Consalve discovers that his beloved and his friends have betrayed him to further their personal ambitions. Disillusioned, he is dismissed from the court and decides to retire anonymously from public life. Moreover, his devastating experience with the deceitful Nugna Bella has convinced him that he will never love a woman again.

However, the encounter with the exotic lady on the beach has revived his sensibilities, and soon he is irresistibly in love with her. He suspects that he makes her sad because he resembles her lost lover, and he tries to find out her prehistory. Just when he is learning Greek because he surmises that that is her mother tongue, she and her servant are suddenly led into a boat by some strange men and taken away. Convinced that he will never meet her again, he considers leaving Spain and joining the Emperor of Constantinople in his struggle against the Saracens. However, later their paths cross twice, once when he hears only her voice and once when he sees her from afar. After Alphonse has recounted his life story, an account dominated by his pathological jealousy, which destroyed a seemingly ideal love-match, Consalve is traced by his former servant, who takes him back to the royal court.

The second part of the novel is set at the royal court amid its entourage, where Don Garcie has now become king. He explains to Consalve what has happened: with the support of Consalve's father Don Garcie gathered troops to force the king to resign. With the support of the counts he acceded to the throne and married Consalve's sister. Now they want to reconcile with him and give him a position in the army to fight the Moors. Consalve accepts, but his mood remains clouded because he misses his beloved. As luck would have it, when a town is captured from the Moors, Consalve visits a castle where a group of Moorish ladies is held captive and he finds his beloved, Zaïde, among them. They can now communicate, since she has learned Spanish and he can speak Greek. Coincidentally, Consalve severely wounds a Moorish prince called Alamir, who turns out to be Zaïde's suitor, who is a nephew of the 'Calife Osman' and who aims to marry her with the support of her father Zuléma, the commander of the Moorish army. Zaïde has refused, however. Her servant Félime tells Consalve about their adventures that ended with shipwreck on the Catalan coast. Finally, Zuléma and the Moorish army are defeated by Don Garcie and Consalve and a peace treaty is signed.

The various misunderstandings and intrigues are now quickly resolved, since communication can finally be established. Alamir appears to be a scoundrel, albeit not without a tragic side; he is spurned by Zaïde and dies of the 
wounds inflicted by Consalve. Félime, after telling Consalve Zaïde's life story, dies out of grief for Alamir. Zaïde discovers that a medallion in her possession showing the portrait of an Arab prince is in fact a representation of Consalve in Moorish attire. Once, when she and her father were in Alexandria, a soothsayer foretold that this portrait was of the prince whom she would marry. This is the reason why the sight of Consalve had distressed her so: the resemblance was clear, but she was convinced that he, being a Christian, could never marry her. It turns out that Zaïde's Greek grandmother was a sister of Consalve's father. After Zuléma, Zaïde's father, has converted to the Christian faith there remain no more obstacles to a happy ending: the marriage of Consalvo with Zaïde.

Although the basic pattern of the story seems simple and schematic at first sight, there are several aspects that differentiate it from the earlier romances. We find some familiar tropes, such as peregrinations on the Mediterranean, storm, and shipwreck, duels, abduction, etc. We also find the key interests of the romance genre, the prominent place of religion, the preponderance of social conventions, and the effort of individual heroes to reconcile these conventions with their inner urges and individuality, in the form of love. Finally, as said above, we find the convergence of cultural and political boundaries, which are porous and strict at the same time, symbolizing impermeability but in fact allowing communication and exchange, due to the contingencies of war, the sea, storms, and love. Other characteristics of the romance are absent, such as tournaments, the codes of knighthood, and, especially, supernatural interventions. Of course, the prediction by the Alexandrian soothsayer plays a decisive role in the plot, but it is defined rather as a coincidence than as a case of real clairvoyance.

A main difference between Zaïde and the romance genre is the novel's form. The story is not constructed as a straightforward account, but as a kind of frame story, consisting of a main line and inserted stories that explain the causes and occasions that resulted in the situation at hand. Consalve's story, Alphonse's story, Don Garcie's story, Félime's stories about Zaïde and Alamir are all incorporated as separate tales that carry the clues to help us understand the narrative as a whole, gradually adding new information to enable the reader to unravel the plot without losing suspense. This narrative layer is supplemented with other textual elements, such as letters. The inserted stories are not only meant to postpone and temporally arrange the components of the plot; they also have a significance in themselves, especially as examples of various forms of love, Consalve's tragic, self-sacrificial love, Don Garcie's pragmatic love, Alphonse's jealous love, Alamir's combination of opportunistic and true love, and Zaïde's all-embracing, romantic love. Every form of love has its 
psychological complications, either because the intentions of the lover thwart 'true' love, or because manipulations and circumstances create impediments and passion has to be mentally reconfigured.

The labyrinthine structure of the story coincides with the mental and physical state of the main protagonists. After his setbacks in Leon, Consalve enters a liminal phase, marked by his leaving the town and ending up in an isolated cottage, and even considering setting out on a desperate journey to the East. He is detached from his surroundings and emotionally broken, and therefore susceptible to events and impressions that will transform him and his life. Similarly, Zaïde is adrift, too, roaming the seas with her father, who has forfeited the caliphal throne and is pushed to the margins of power, ending up in a long battle against the infidels in Spain. Zaide herself is, on the one hand, entangled in the structure of hierarchy and social conventions imposed by her society, but she is also wilful and autonomous, because she believes in her intuition and feelings. True love should overcome her loneliness and 'captivity', but before this can be achieved, she has to be shorn loose by fate and thrown into the chaotic phase that severs the ties with her surroundings, governed by authority, prohibitions, and conventions.

The liminal phases in which Zaïde and Consalve find themselves are required to make their meeting possible. The only way in which they can cross the seemingly impermeable boundaries and can escape the authority structuring them is by escaping the forces governing their lives, either by conceding to despair or by accepting the uncertain whims of fate. And the only way to reach this state and to enter this phase of uncertainty is to believe in the power of true love. Only this belief can efface the boundaries and restrictions imposed on their love and allow them to enter a no-man's land in which political and cultural barriers are temporarily suspended. It is, simultaneously, a psychological no-man's land, which requires contemplation and investigation before some order can be re-established: the protagonists have to be initiated into the various manifestations of love and have to establish a way to communicate. Only then can a psychological condition be realized that makes a harmonious union possible.

The complex structure of the novel is used, too, to highlight one of the main themes of the novel, which dominates the lives of the protagonists: the difficulty of communicating, of mutual understanding and of grasping the real nature of the situation behind its appearances. Thus, the inserted stories emphasize that the characters have evaluated their situation incorrectly, because they had insufficient information or interpreted the information that they had incorrectly. Like the reader, the characters have to gradually discover the story in which they are staged. Consalve is in permanent search to find 
out what is happening to him, not only his feelings for Zaïde, but also the schemes of his friends at the royal court. His investigations are hampered by a persistent miscommunication and the inability to find communicative means: he discovers the betrayal of Nugna Bella only through a misdirected letter; he lacks a common language to speak with Zaïde; he is unaware that he is fighting with Prince Alamir, his rival in love; and, finally, he is unfamiliar with the true nature of love.

The story depicts Consalve's confusion as a juxtaposition of various discursive domains, which both Zaïde and Consalve have to explore, but which seem never to match. The first discursive domain is, of course, language, which proves to be an unsurmountable obstacle when Zaïde and Consalve first meet. Since they have no common language, they are both not merely condemned to silence, but actually mute and unable to communicate even the minutest information about themselves, let alone their visions of love and destiny. Second, the two are separated by the discursive boundaries between men and women, reflecting not only diverse social environments, but also predisposed attitudes towards love and the discourses in which they are caught. Third, Consalve attempts to open up a common domain by depicting their situation, as he envisions it, in a painting, which should bridge the gap of their linguistic incompatibility. This fails, however, because he is unable to formulate a common interpretation of what is shown. Conversely, Zaïde has a mysterious medallion with the portrait of an Arab prince, whose meaning she is unable to convey. Fourth, both Zaïde and Consalve are restricted by their cultural backgrounds. Zaïde has all the outward characteristics of an Oriental lady, beautiful but mysterious, unreachable and exotic. At the same time, she is within Consalve's cultural 'domain', displaced and intruding as a discursive 'alien'.

In all these domains the discursive incongruities between Zaïde and Consalve have to be harmonized in one way or another. This seems to be what the story is about, as is suggested by both its form and the efforts of the protagonists: the boundaries preventing communication and a common understanding have to be overcome, and this can be done only by establishing channels within all these domains. It is no coincidence that the key to the solution of Zaïde and Consalve's predicament is the medallion with the portrait. The portrait is in the end interpreted by using their common languages, Spanish and Greek; it explains the nature of Zaïde's love, based on a prediction; by being identified as representing Consalve, it solves the problem of visual interpretation; by explaining the incorrect identification by pointing at Consalve's Moorish dress, attention is directed at the possibilities of cross-cultural identification and communication. The medallion symbolizes the possibility of communication, as a common 'medium' enabling the trajectories of the two lovers to cross, 
accompanying them on their peregrinations, and, finally, establishing the coveted union. It is the medallion that is, in the end, the instrument of fate.

However, this is not the whole story. All the adventures and struggles of Zaïde and Consalve are structured not only by discursive and cultural incongruities and interactions, but also, and predominantly, by political frameworks. It is no coincidence, of course, that the author chose historical material as the basic stratum of her narrative. The intrigue of the vicissitudes of the protagonists is tightly interwoven with the military and political confrontation between Christianity and Islam, and the ways in which it structures power relations, social structures, and cultural boundaries. The lives and trajectories of the two lovers are steered by their confrontation, and their union coincides with its outcome. The phases of swerving, love exchange, and union are paralleled by the phases of the campaign of Don Garcie against the Moors, his coup d'état, his military expedition, and his final victory. His victory, co-achieved by Consalve, opens up the possibility of a denouement that, inevitably, consists of the triad political truce, conversion, and consent to marriage. The political framework has to be reshaped to allow for a legitimate marriage, but, it can be argued, political harmony is preconditioned by marital relations.

It is in the combination of politics and love that the narrative of kingship in Zaïde has to be sought. The adventures of Zaïde and Consalve are not only steered by political circumstances; they are also firmly embedded in relations of power. Consalve, living at the court of Leon, is completely subjected to the forces of power and the intrigues generated by them. He is the victim of the ambitions of his peers and of the prominent position of his father. Because of his integrity, he is crushed by forces he is unable to grasp or influence. His only solution is to withdraw in search of an 'initiation' of another kind, which fits his uncompromising personality. Zaïde, too, is the victim of machinations and power games, implicated in her father's position and — frustrated—ambitions, combined with the restrictions on women imposed on her by a thoroughly patriarchal society. She, too, is crushed because she refuses to accommodate to these forces and upholds her loyalty to her vision of true love. As a woman, she is unable to escape, but fate comes to her rescue and enables her to, at least temporarily, leave her restricted domain.

For Consalve, the liminal phase is ended by the seizure of power by Don Garcie and the revealing of his true intentions. This change makes possible the re-integration of Consalve, in his full integrity, and enriched by the experience of love. His re-integration is completed, of course, only when he is able to call Zaïde his own. In turn, Zaïde is forcefully re-integrated into her milieu, but reaches her destiny only when the oppressive forces are removed by defeat, death, and conversion, which effectuates the crumbling of the power structure 
imprisoning her. The whole new configuration is sealed when it turns out that Zaïde and Consalve are distant relatives, smoothing all the potentially disruptive details forever. The interactions between political and personal elements bring about in the end the positive denouement.

It is in the combination of the two levels of the story that the discourse of royal power is rooted. At first sight we find a familiar picture: an emperor in Constantinople-now conveniently marginalized — and a king in Spain, opposed by a caliph and a Moorish king respectively. And both sides have their most prominent knights, who are not, however, bound to the codes of knighthood, but rather follow their own inclinations and designs. Although the king is all-powerful, still authority is composite; as in the romances of chivalry, the hero is not the king, but his fiercest warrior, who, again, personifies the values of the community. These values are here not expressed in martial exploits and campaigns, however; the focus is rather on a struggle of another kind: the hero's efforts to find harmony by removing not only the rivalling knight, but also the obstacles hampering mutual understanding and perpetuating misunderstandings from the past. His contribution to the consolidation of the throne is not so much in defeating the enemy, but rather in conquering a space for communication and discursive exchange, all encompassed by the enormous force of love. The narrative thereby contains the main ingredients of the romance, but the textual complexity and the change of emphasis have turned it into a completely different genre, changing, too, the discursive embedding of royal authority.

\section{Concluding Remarks}

It is no exaggeration to say that social structures, hierarchies, and conventions are to a large extent intended to regulate gender relationships and their effects on the coherence of the community. After all, sexual relations tend to have a disruptive influence on rational conceptions of social order and, thereby, the control of social stability. It is no wonder then that gender relations are a crucial component of fictional literature, which serves as a medium to embed social relations in a collective imagination. It is also logical that they play an important role in imaginings of kingship. The main dilemmas posed in fictionalized representations of the connection between gender relations and kingship arise from the fact that love and sexuality may threaten the continuity of the dynasty by potentially breaking social rules and institutions, while at the same time they are indispensable for the continuation of the dynasty. In premodern societies and literatures this tension is usually dealt with by 
installing a strong regime of patriarchal power, but this stratagem contributes to the polarization between the sexes and an accumulation of destructive energies. And, to be sure, a balance between male and female elements is conducive to the stability of authority and the charisma of the king.

As we have argued elsewhere, ${ }^{34}$ one of the functions of the relations between love and kingship in romances is not only the account of an initiation, but also the visualization of what may be called the 'management of desire'. Desire, in the Freudian sense, is usually depicted as the urge in a prince to find his destiny, that is, his replacing his father as a king, through displaying his powers and conquering his beloved, as proof of his masculinity and as the embodiment of social order. In the patriarchal mind, women are perhaps not without a will of their own, but in the end still more an object than an agent in this process. Nevertheless, by representing a potential threat to a supposedly selfevident order, women are the instigators of narrative explication and dialogic processes. Put bluntly, without women there would be no narrative of kingship, because they necessitate a layered and diversified vision of authority required for producing narratives. Therefore, although all stories discussed in this chapter are fundamentally misogynous and exude a deep fear of women, they also seem to acknowledge that without women kingship makes no sense.

If we confine ourselves to the theme of love, rather than gender relations in general, we find that in spite of its disruptive potential, and in spite of its patriarchal connotations, it is filled with positive values. Love can be seen as a symbolic container of positive physical, psychological, social and, moral properties, imbuing a king and a society with an image of harmony, integrity, and stability. Love is the force making visible the ideal values of a community, legitimizing specific human relationships, and breaking boundaries that seemed impenetrable. As such, it represents the fulfilment of destiny and thereby the legitimation of a specific role. Love, in its confined form as the unleashing and containment of desire, is ultimately the manifestation of fate.

Van Leeuwen, The Thousand and One Nights. 